\title{
Technology Readiness and E-Commerce Adoption among Entrepreneurs of SMEs in Bandung City, Indonesia
}

\author{
Novika Candra Astuti ${ }^{a^{*}}$ and Reza Ashari Nasution ${ }^{2}$ \\ ${ }^{a}$ School of Business and Management, Institut Teknologi Bandung
}

\begin{abstract}
The emergence of internet-based electronic commerce offers considerable opportunities for companies to expand their customer base, enter new product markets, and rationalize their business. The Indonesian government has initiated and implemented a series of plans and activities to promote technology use to increase SMEs' performance. Despite such efforts, technology adoption rate are still low. Therefore, it is important to understand the factors affecting an entrepreneurs' decision on internet adoption, by measuring technology readiness (TR). The purpose of this study is to investigate TR and the extent to which E-commerce is adopted amongst entrepreneurs. This study is replication of Parasuraman's study on the Technology Readiness Index (TRI). Questionnaires were distributed using a convenience sampling method to 190 entrepreneurs of SME in Bandung city. The findings indicate that entrepreneurs are moderate in terms of their TR. There are significant differences in terms of TR across entrepreneurs' backgrounds (gender, age, education, and income). In relation to internet adoption by those surveyed, as their use of media promotion is still low, there were only 36.3 percent who adopted it. The results clearly indicate the need to provide support to SMEs to adopt and use e-commerce. These results have implications not only for managers of SMEs but also for government agencies in developing countries such as Indonesia. The findings have implications for researchers and practitioners by identifying TR drivers (optimism and innovativeness), and barriers (discomfort and insecurity), that contribute to effectively leveraging the Internet in an important area for SMEs.
\end{abstract}

\begin{abstract}
Abstrak: Munculnya perdagangan berbasis internet menawarkan peluang yang cukup besar bagi perusahaan untuk memperluas jumlah pelanggan, memasuki pasar baru, dan merasionalisasikan bisnis mereka. Pemerintah Indonesia telah menerapkan serangkaian rencana dan kegiatan untuk mempromosikan penggunaan teknologi untuk meningkatkan kinerja Unit Kecil Menengah (UKM). Meskipun berbagai upaya pemerintah telah dilakukan, namun tingkat adopsi teknologi masih rendah. Oleh karena itu, penting untuk memahami faktor-faktor yang mempengaruhi keputusan seorang entrepreneur dalam mengadopsi internet yaitu dengan mengukur kesiapan teknologi. Tujuan dari penelitian ini adalah untuk mengetahui kesiapan teknologi dan sejauh mana tingkat adopsi e-commerce para entrepreneur di UKM. Penelitian ini merupakan replikasi dari penelitian Parasuraman tentang Indeks Kesiapan Teknologi (Technology Readiness Index/TRI). Kuesioner didistribusikan menggunakan metode convenience sampling kepada 190 entrepreneur UKM di kota Bandung. Hasil penelitian menunjukkan bahwa kesiapan teknologi dari entrepreneur masih moderat. Ada perbedaan yang signifikan dalam hal kesiapan teknologi jika dilihat dari latar belakang
\end{abstract}

* Corresponding author's e-mail: novika.candra@sbm-itb.ac.id

ISSN: $1141-1128$

http://www.gamaijb.mmugm.ac.id/ 
mereka (jenis kelamin, usia, pendidikan, dan pendapatan). Sehubungan dengan tingkat adopsi internet untuk media promosi masih rendah, hanya ada 36.3 persen yang mengadopsinya. Hal ini jelas menunjukkan perlunya untuk memberikan dukungan kepada UKM untuk mengadopsi teknologi khususnya untuk penggunaan e-commerce. Hasil penelitian memberikan implikasi tidak hanya untuk para manajer UKM tetapi juga untuk instansi pemerintah di negara-negara berkembang seperti Indonesia. Temuan ini juga memiliki implikasi bagi para peneliti dan praktisi dalam mengidentifikasi pendorong kesiapan teknologi (optimisme dan inovasi) dan hambatan (ketidaknyamanan dan ketidakamanan), yang berkontribusi secara efektif membantu meningkatkan penggunaan internet di UKM.

Keywords: e-commerce; entrepreneurs; SMEs; technology readiness

\section{Introduction}

Internet technology has changed the supply chain by improving collaboration and efficiency, and adding value to products and firms. The rapid adoption of the internet as a commercial medium has motivated firms to experiment with innovative ways of marketing in cyberspace (Ricciuti 1995). Electronic commerce (e-commerce) refers to the use of the Internet for buying and selling activities (Rodgers et al. 2002). E-commerce can be one of the activities which create value for companies wanting to improve their business. As a direct impact, e-commerce enables the automation of common processes, such as distribution, sales, after-sales service and inventory management. Driven by the growth of the Internet and economic globalization, e-commerce has become critical in many organizations, both large and small.

Small and Medium-sized Enterprises (SMEs) are gradually using information and communications technologies (ICT)-based electronic commerce to gain competitive advantages, and to have access to global markets (Al-Qirim 2003). Around the world, SMEs are increasingly seen as essential for economic diversification through job creation (Machacha 2002). As evidence of the impor- tance of SMEs to the national and international economy, and the potential of internet adoption and utilization in the context of SMEs, it becomes important to understand the key issues that determine the adoption of the Internet (Houghton and Winklhofer 2004; Pflughoeft et al. 2003). It is on record that a variety of potential profits can be made by e-commerce, but surprisingly adoption by SMEs' of e-commerce is still low, as SMEs have different characteristics to those of large companies.

In the history of the Indonesian economy, SMEs constitute the largest group of economic actors that have contributed significantly to the national economy and have proved to be a buffer in the economy. Based on data from the State Ministry for Cooperative and SME in 2012, it stated that the contribution of SMEs in Indonesia is also very real with the number estimated to be $55,213,960$ business units or 99.98 percent of the total business with 99.04 percent absorption of labor employment, equivalent to 101.72 million people. Similarly, SME's contribution to non oil Gross Domestic Product (GDP) was 63.11 percent, with an investment of 640.4 trillion or 52.9 percent as well as contributing to exports of 183.8 trillion or 20.2 percent. The Indonesian government is 
actively supporting the use and utilization of IT to increase the competitiveness of SMEs. However, currently IT adoption by SMEs in Indonesia is still very low.

With the coming implementation of the ASEAN Economic Community in 2015, each country has to prepare, as do SMEs in Indonesia. However, SMEs appear to face significant and unique challenges in adopting new technologies. The technology readiness of each individual SME is not the same, although there is a growing awareness about the potential of e-commerce. SMEs have begun to utilize the potential of the Internet, although most are still only at the stage of marketing and product promotion. Technological readiness is concerned with the level of sophistication of IT usage and IT management in an organization (Iacovou et al. 1995). IT sophistication (Pare and Raymond 1991) captures not only the level of technological expertise within the organization, but also assesses the level of management understanding of, and support for using IT to achieve organizational objectives. This factor was considered because small firms tend to lack the resources that are necessary for IT investments (Bouchard 1993). Therefore, there is a need for better understanding of the reasons why SMEs use technologies, in an effort to establish practical methods aimed at assessing the technology, how users will respond to them, and elevate user acceptance through the changing nature of the technologies and processes they implemented.

The objectives of this study, therefore, are to investigate technology readiness and the extent to which e-commerce adoption among entrepreneurs occurs. This study is a replication of Parasuraman's study on the Technology Readiness Index (TRI). Our literature review shows little research has been done incorporating user technology readiness into studying technology adoption among entrepreneurs in SMEs. We believe that technology readiness dimensions as personality traits serve as an important factor in influencing user perception of technology, such as e-commerce. Understanding potential entrepreneurs' technology readiness and their perceptions concerning certain products and services could provide new insight in both academia and practice in understanding readiness in adopting technology, and also elevate technology use in SMEs. This study has limitations on e-commerce adoption only in the areas of marketing and product promotion. A study of this nature is helpful and timely for filling the gap in the literature, and for building Technology Readiness theory to entrepreneurs' life reality in Indonesia. This type of research should also be helpful for comparing the findings from different countries, and for examining the guiding value of a theory on a world-wide scale.

\section{Literature Review}

\section{Technology Readiness}

In management and marketing theory, personality differences have been regarded as important in moderating human behavior. The literature tells us that personality can be described as the aspects of an individual's thoughts and behavior that are stable over time and relatively consistent across different situations (Roberts and DelVecchio 2000). A previous study showed that the use of selfservice technology (SST) is heavily influenced by user personality traits, since personality affects the environment people choose and the speed with which they adapt to a new technology (Pocius 1991). 
This study focused on entrepreneurs in, and owners of SMEs. Harper (1996) sees the entrepreneur as one who is engaged in entrepreneurial, often identified as an innovator a person who attempts to introduce, on a commercial basis, new products, new productive techniques, or even new forms of business enterprise. The focus on entrepreneurs is highlighted by the fact that entrepreneurs are a different and important IT user group. This study applied Parasuraman's study about technology readiness. Technology readiness (TR) refers to "people's propensity to embrace and use new technologies to accomplish goals in home life and at work" (Parasuraman 2000). At the measurement level, the Technology Readiness Index (TRI) was developed to measure people's general beliefs and thoughts about technology. It is a combination of positive and negative technology-related beliefs. The variable can be viewed as an overall state-of-mind which determines a person's predisposition to use new technologies. There are four variables in technology readiness:

- Optimism is defined as "a positive view of technology and a belief that it [technology] offers people increased control, flexibility, and efficiency in their lives." It generally captures positive feelings about technology.

- Innovativeness is defined as "a tendency to be a technology pioneer and thought leader." This dimension generally measures to what degree individuals perceive themselves as being at the forefront of technology adoption.

- Discomfort is defined as "a perceived lack of control over technology and a feeling of being overwhelmed by it." This dimension generally measures the fears and concerns people experience when confronted with technology.
- Insecurity is defined as a "distrust of technology and skepticism about its ability to work properly." This dimension focuses on concerns people may have in the face of technology-based transactions.

Optimism and innovativeness are "contributors" that increase an individual's technology readiness, while discomfort and insecurity are "inhibitors" that reduce technology readiness. We believe that technology readiness variables as personality traits serve as an important factor in influencing the entrepreneur's perception of technology in doing business, such as e-commerce. The technology cannot be accepted if the entrepreneur is not ready. Meuter et al. (2005) referred to customer readiness as a condition or state in which a consumer is prepared and likely to try new technology services; it can be conceptualized as role clarity, motivation, and ability. In previous research, Jaafar et al. (2007) examined influence demographic background on the technology readiness level. They found that the overall TRI score among managers of Malaysian construction firms was moderate in terms of their technology readiness. There were no significant differences in terms of TRI across various demographic variables (e.g. gender, age, etc.), except for educational level. Demirci and Ersoy (2008) replicated and extended Parasuraman's study on Technology Readiness Index (TRI). They found that none of the factors of technological readiness were statistically different according to educational level and average income.

\section{SMEs and E-commerce}

E-commerce refers to conducting business transactions over the Internet, which includes exchange of information of value, in the form of products and services as well as payments, using web-based technologies 
(Fraser et al. 2005). E-commerce can enhance the supply chain efficiency by providing real-time information regarding product availability, inventory level, shipment status, and production requirements (Radstaak and Ketelaar 1998). SMEs are regarded as having an important role in the economies of both developing and developed countries. It should be noted that various potential advantages can be created by e-commerce, but surprisingly SMEs' adoption of e-commerce has still been limited due to the fact that SMEs have different characteristics from large enterprises. Under the opinion of Seyal and Rahman (2003), distinct characteristics imbedded in SMEs consist of small management teams, strong owner influence, lack of staff in specialized areas such as information technology, multi-functional management, limited control over their business environment, limited market share, low employee turnover, a reluctance to take risks, and avoidance of sophisticated software or applications. Such characteristics lead SMEs to be very slow with respect to technology adoption, and have more difficulties in taking advantage of benefits from the technologies than large enterprises (Grandon and Pearson 2004; Poon and Swatman 1999). The e-commerce adoption literature implies that in order to adopt e-commerce appropriately in developing countries, firms need to be internally and externally ready (Tan et al. 2007). Molla and Licker (2005) demonstrated that in the initial adoption of e-commerce in developing countries, internal (organizational) readiness is significantly influential. Internal e-commerce readiness can be defined as availability of financial and technological resources, the top management's enthusiasm to adopt e-commerce, e-commerce technology infrastructure (ECTI), compatibility of ecommerce in firm as well as culture and val- ues (Saffu et al. 2008). The issue of individuals is a critical aspect of the application of ICT and e-commerce in any organization. The challenge comes when the manager is reluctant to push for e-commerce developments. A vibrant SME owner or manager usually transforms the SME's objectives to grow the organization further (Karakaya and Shea 2008). Research studies have found that one of the criteria for successful e-commerce adoption amongst SMEs is the level of education (Thong 1999; Sarosa and Zowghi 2003). SMEs are interested in e-commerce since it can help them to improve their business processes, reduce costs, and achieve close connection with their clients.

\section{Methods}

A survey was distributed to SMEs in Bandung city, Indonesia. This study replicated Parasuraman's study, Technology Readiness Index. TRI is a multiple-item scale developed to measure consumers' readiness to embrace new technologies (Parasumaran 2000). TRI consists of 36 statements that put forward the drivers and inhibitors of technology readiness. The statements were evaluated by the survey participants according to a five-point Likert scale (' 1 ' strongly disagree and ' 5 ' strongly agree). In addition, the survey questioned respondents about their background (gender, age, business sector, education, income) and internet adoption as media promotion as well as the kind of media they used.

The respondents were drawn by using non-probabilistic sampling since this research does not have any list of respondents, therefore, no sampling frame. The survey was conducted from March to June 2013. The managers or owners of SMEs from various sectors located in Bandung were chosen as respondents since they are the most important 
persons in their company or business, and the one who will determine the level of technology use. The survey was distributed to 260 entrepreneurs in various background, some of them are students who also have their own business; the rate of return in this study is 73 percent. So, 190 entrepreneurs participated in this research.

The tools that were used for processing the data were SPSS 19 and Lisrel 8.70. Confirmatory Factor Analysis (CFA) was used in this study by using Lisrel 8.70 . CFA is used to check the validity and reliability of the variables of technology readiness. Then, to find out the research objectives, this study used two types of analyses - t-test and oneway ANOVA in SPSS 19. A t-test is appropriate for two groups and a one-way ANOVA is appropriate for more than two groups. Any significant differences between these groups can be detected by $\mathrm{t}$-values and the $\mathrm{F}$ value for a one-way ANOVA. There is one type of significant difference level $\mathrm{p}<0.05$ which indicates a 95 per cent confidence level.

\section{Characteristics of the Sample}

The questionnaire was distributed to the 190 Bandung entrepreneurs who participated in our survey. Characteristics of the respon- dents are presented in Table 1. This study was conducted in various business sectors. There are 34.2 percent in Culinary, 16.3 percent in Design, Creative Art and Architecture, 16.3 percent in Fashion, 6.3 percent in Electronics-Information Technology, 6.8 percent in Fishery, 5.3 percent in Agriculture, 2.6 percent in Education, 4.2 percent in Stationery, 3.7 percent in Beauty salon and gift shop, and others 4.1 percent (music shops, internet marketing, book store, properti, transportasi/ travel). The majority of participants have owned their business for less than 5 years $(45.8 \%)$, for between $5-10$ years it is 35.8 percent, between $11-15$ years 10.0 percent, between 16-20 years 5.3 percent, and over 25 years 3.3 percent. The participants also have used the internet as media to promote and sell their products. Of the 190 survey participants, 36.3 percent used the internet and 63.7 percent didn't use the internet as media promotion. From 36.3 percent of total respondents using internet as media promotion, 27.3 percent respondents used Facebook, 16.3 percent used own website, 14.2 percent used Twitter, 6.3 percent used Blog, 7.4 percent used Kaskus, 6.8 percent used Toko Bagus, and others 6.8 percent (Instagram, Path, Blackberry Messenger).

Table 1. Characteristics of the Sample

\begin{tabular}{llcc}
\hline & Frequency & Percentage \\
\hline Age & Under 20 years old & 8 & $4.2 \%$ \\
21-25 years old & 29 & $24.7 \%$ \\
26-30 years old & 52 & $15.3 \%$ \\
31-35 years old & 33 & $27.4 \%$ \\
36-40 years old & 14 & $17.4 \%$ \\
Above 40 years old & & \\
& & \\
\end{tabular}


Table 1 (Continued)

\begin{tabular}{llcr}
\hline & & Frequency & Percentage \\
\hline Gender & Male & 98 & $51.6 \%$ \\
Education & Female & 92 & $48.4 \%$ \\
& Elementary school & 14 & $7.4 \%$ \\
& Junior high school & 34 & $17.9 \%$ \\
& Senior high school & 76 & $40.0 \%$ \\
& Diploma & 33 & $17.4 \%$ \\
Monthly Income & Bachelor's degree & 27 & $14.2 \%$ \\
& Master's degree & 6 & $3.2 \%$ \\
& Less than Rp 3,000,000 & 59 & $31.1 \%$ \\
Internet use as & Rp 3,000,000-Rp 5,000,000 & 54 & $28.4 \%$ \\
media promotion & Rp 5,000,000-Rp 7,000,000 & 10 & $5.3 \%$ \\
& Over Rp 10,000,000 & 17 & $8.9 \%$ \\
& Yes & 50 & $26.3 \%$ \\
& No & 69 & $36.3 \%$ \\
& & 121 & $63.7 \%$ \\
\hline
\end{tabular}

\section{Technology Readiness Analyses}

There are 36 items in total which may drive or inhibit technology readiness in the TRI measurement scale of Parasuraman. To classify and sort out the variables, Confirmatory Factor Analysis (CFA) was used in this study by using Lisrel 8.70. After processing the data with CFA, eleven items with factor loadings of less than 0.50 were excluded from the original scale, and the final analysis was performed on 24 items. All factor loadings are greater than 0.50 . The cronbach alphas are greater than 0.70 as suggested by Nunnally (1978), except for innovativeness, but for this value some researchers state that more than 0.6 is still acceptable. All factors have a relatively high coefficient score (see

T-test and Anova were applied to examine the demographic differentiations of the four variables of technology readiness (Table
3). According to the gender variable, innovativeness was found to be significantly different compared to the other variables. Based on the t-test results for innovativeness, males are more interested in technology than are females, as can be seen in Figure 1. In term of age, innovativeness and discomfort were significantly different. Depending on their education, optimism, innovativeness, discomfort and insecurity were found to be significantly different. Figure 4 shows that entrepreneurs with a high level of education have high optimism and innovativeness, but they also have a high level of discomfort and insecurity compared to lower educational group. The overall TRI score shows that entrepreneurs with a degree-level education have a higher technology readiness compared to those with a lower education. With regards to income, optimism, discomfort, and insecurity were found to be significantly differ- 
ent compared to the other variables. Figure 3 shows that entrepreneurs with higher income levels have high optimism, but also have more discomfort and insecurity compared to those with a lower income. According to the busi- ness sector, we found that innovativeness and discomfort were significantly different. In term of internet use, we found that discomfort was significantly different compared to other variables.

\section{Table 2. Measurement Scores}

\begin{tabular}{|c|c|c|c|c|c|}
\hline Items & & $\begin{array}{l}\text { Factor } \\
\text { Loading } \\
(>0.5)\end{array}$ & Mean & S.D. & $\begin{array}{l}\text { Cronbach's } \\
\text { Alpha }\end{array}$ \\
\hline \multicolumn{6}{|c|}{ OPTIMISM } \\
\hline OP1 & $\begin{array}{l}\text { (Technology gives people more control } \\
\text { over their daily live) }\end{array}$ & 0.61 & 3.789 & 0.853 & \\
\hline OP2 & $\begin{array}{l}\text { (Products and services that use the } \\
\text { newest technologies are much more } \\
\text { convenient to use) }\end{array}$ & 0.54 & 3.678 & 0.767 & \\
\hline OP3 & $\begin{array}{l}\text { (Technology makes you more } \\
\text { flexible doing business because you } \\
\text { are not limited to regular business hours) }\end{array}$ & 0.65 & 3.684 & 0.773 & \\
\hline OP5 & $\begin{array}{l}\text { (You like computer programs that allow } \\
\text { you to tailor things to fit your own needs) }\end{array}$ & 0.80 & 3.778 & 0.805 & 0.885 \\
\hline OP6 & $\begin{array}{l}\text { (Technology makes you more efficient } \\
\text { in your occupation) }\end{array}$ & 0.78 & 3.90 & 0.72 & \\
\hline OP7 & $\begin{array}{l}\text { (You find new technologies to be } \\
\text { mentally stimulating) }\end{array}$ & 0.72 & 3.50 & 0.88 & \\
\hline OP8 & $\begin{array}{l}\text { (Technology gives you more freedom } \\
\text { of mobility) }\end{array}$ & 0.78 & 3.83 & 0.75 & \\
\hline \multirow[t]{2}{*}{ OP10 } & $\begin{array}{l}\text { You feel confident that technology will } \\
\text { follow through with you instructed them } \\
\text { to do) }\end{array}$ & 0.75 & 3.78 & 0.72 & \\
\hline & & 3.74 & 0.79 & & \\
\hline \multicolumn{6}{|c|}{ INNOVATIVENESS } \\
\hline INO4 & $\begin{array}{l}\text { (You can usually figure out new high-tech } \\
\text { products without help from others) }\end{array}$ & 0.58 & 2.81 & 0.88 & \\
\hline INO5 & $\begin{array}{l}\text { You keep up with the latest technological } \\
\text { developments in your areas of interest) }\end{array}$ & 0.58 & 3.35 & 0.81 & \\
\hline INO6 & $\begin{array}{l}\text { (You enjoy the challenge of figuring out } \\
\text { high-tech gadgets) }\end{array}$ & 0.67 & 3.31 & 0.78 & 0.675 \\
\hline \multirow[t]{2}{*}{ INO7 } & $\begin{array}{l}\text { You find you have fewer problems } \\
\text { than other people in making technology } \\
\text { work for you) }\end{array}$ & 0.52 & 3.11 & 0.83 & \\
\hline & & 3.15 & 0.83 & & \\
\hline
\end{tabular}


Table 2 (Continued)

\begin{tabular}{|c|c|c|c|c|}
\hline Items & $\begin{array}{c}\text { Factor } \\
\text { Loading } \\
(>0.5) \text { Items }\end{array}$ & Mean & S.D. & $\begin{array}{c}\text { Cronbach's } \\
\text { Alpha }\end{array}$ \\
\hline
\end{tabular}

\section{DISCOMFORT}

DISCOM1 (Technical support lines are not helpful

$\begin{array}{llll}0.64 & 2.88 & 0.86 & 0.835\end{array}$

because they do not explain things you understand)

DISCOM2 (Sometimes, you think that technology systems are no designed for use by ordinary people)

$\begin{array}{lll}0.61 & 2.77 \quad 0.94\end{array}$

DISCOM3 (There is no such thing as a manual for a high-tech product or service that's written in plain language)

$\begin{array}{lll}0.81 & 2.80 & 0.89\end{array}$

DISCOM4 (When you get technical support from a provider of high-tech product or service, you sometimes feel as if you are being taken advantage of by someone who knows more than you do)

DISCOM5 (If you buy a high-tech product, you prefer to have the basic model over one with a lot of extra features)

DISCOM7 (You find new technologies to be mentally stimulating)

DISCOM9 (Learning about technology can be as rewarding as the technology itself)

$0.63 \quad 2.74 \quad 0.81$

$\begin{array}{lll}0.73 & 2.89 & 0.89 \\ 0.59 & 3.10 & 0.97 \\ & & \\ 0.55 & 3.21 & 0.91 \\ 0.55 & 3.21 & 0.91 \\ \mathbf{2 . 9 1} & \mathbf{0 . 8 9} & \end{array}$

\section{INSECURITY}

INSE1 You do not consider it safe giving out a credit card number over a computer)

$\begin{array}{llll}0.58 & 3.6800 & 0.81 & 0.793\end{array}$

INSE3 (You worry that information you send over the internet will be seen by other people)

$\begin{array}{lll}0.63 & 3.6947 & 0.77\end{array}$

INSE6 (Whenever something gets automated, you need to check carefully that the machine or computer is not mistakes)

$0.64 \quad 3.8000 \quad 0.86$


Table 2 (Continued)

\begin{tabular}{llcccc}
\hline Items & & $\begin{array}{c}\text { Factor } \\
\text { Loading } \\
(>\mathbf{0 . 5}) \text { Items }\end{array}$ & Mean & S.D. & $\begin{array}{c}\text { Cronbach's } \\
\text { Alpha }\end{array}$ \\
\hline INSE7 & $\begin{array}{l}\text { (The human touch is very important } \\
\text { when doing business with a company) }\end{array}$ & 0.74 & 4.0526 & 0.92 & \\
INSE8 & $\begin{array}{l}\text { (When you call a business, you prefer } \\
\text { talk to a person rather than a machine) }\end{array}$ & 0.70 & 3.8421 & 0.86 & \\
TRI & & $\mathbf{3 . 8 1}$ & $\mathbf{0 . 8 4}$ & \\
\hline
\end{tabular}

Table 3. Aspect Differentiation According to Demographic

\begin{tabular}{lccccc}
\hline Variables & & Optimism & Innovativeness & Discomfort & Insecurity \\
\hline Gender & $\mathrm{t}$ & 0.201 & 2.361 & 1.860 & -0.367 \\
Age & $\mathrm{p}$ & 0.147 & $0.000^{*}$ & 0.560 & 0.617 \\
& $\mathrm{~F}$ & 1.870 & 4.022 & 6.171 & 1.263 \\
Education & $\mathrm{p}$ & 0.102 & $0.002^{*}$ & $0.000^{*}$ & 0.282 \\
& $\mathrm{~F}$ & 7.066 & 8.153 & 3.070 & 2.711 \\
Income & $\mathrm{p}$ & $0.000^{*}$ & $0.000^{*}$ & $0.011^{*}$ & $0.022^{*}$ \\
& $\mathrm{~F}$ & 3.122 & 1.478 & 8.882 & 15.615 \\
Sector Business & $\mathrm{p}$ & $0.016^{*}$ & 0.210 & $0.000^{*}$ & $0.000^{*}$ \\
& $\mathrm{~F}$ & 1.1773 & 2.008 & 4.776 & 1.126 \\
Internet adoption & $\mathrm{p}$ & $0.042^{*}$ & $0.017^{*}$ & $0.000^{*}$ & 0.336 \\
& $\mathrm{t}$ & 4.497 & 3.808 & 4.202 & -0.739 \\
& $\mathrm{p}$ & 0.653 & 0.102 & $0.044^{*}$ & 0.986 \\
\hline
\end{tabular}

* Significance $p$-value $<0.05$ 
Gadjah Mada International Journal of Business -Jamuary-April, Vol. 16, No. 1,2014

Figure 1. Male-Female Comparison

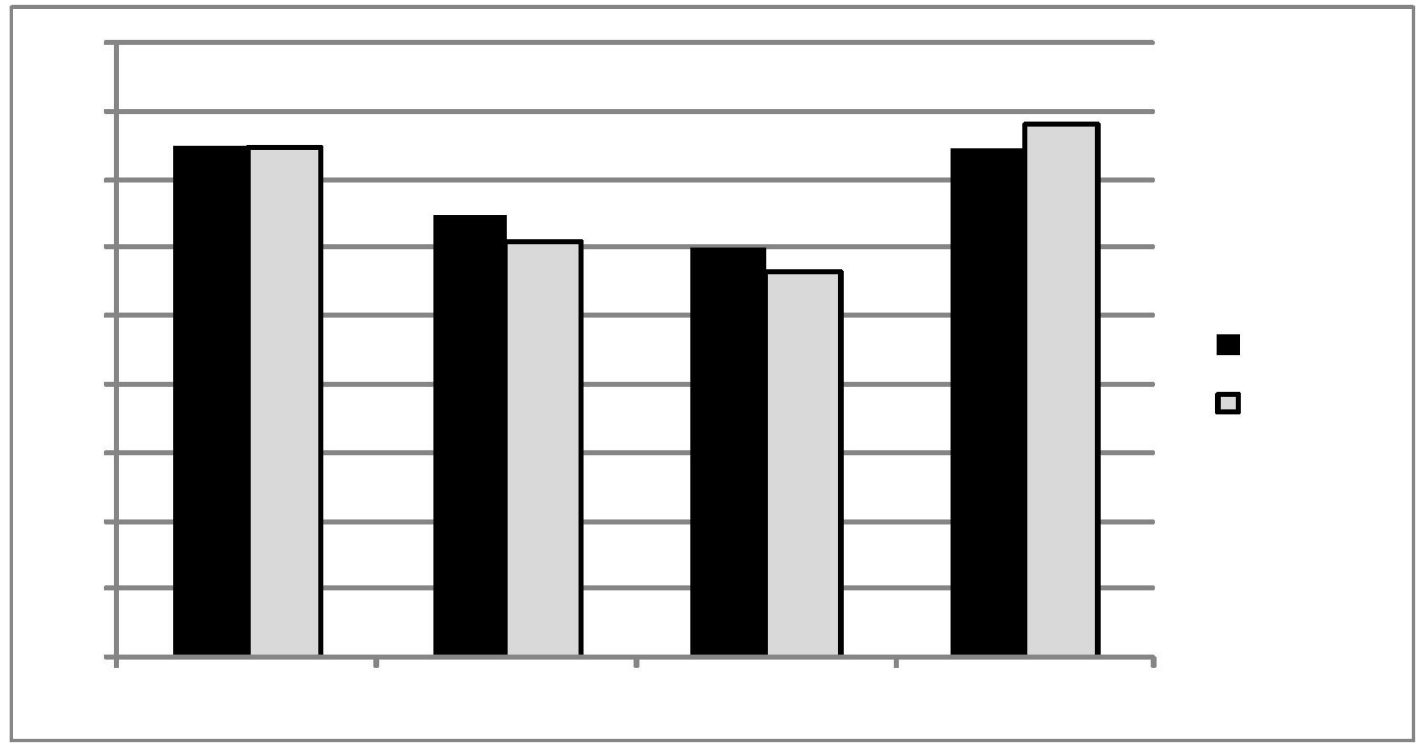

Figure 2. Age Group Comparison

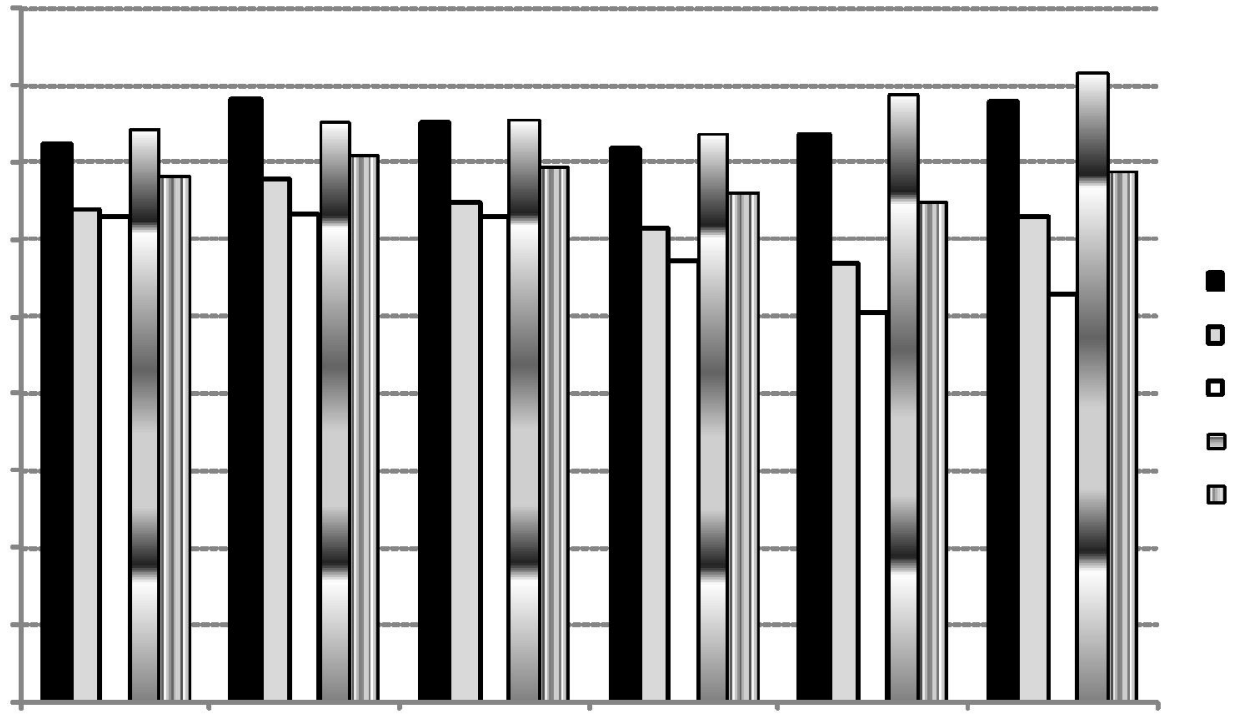


Figure 3. Income Level Comparison

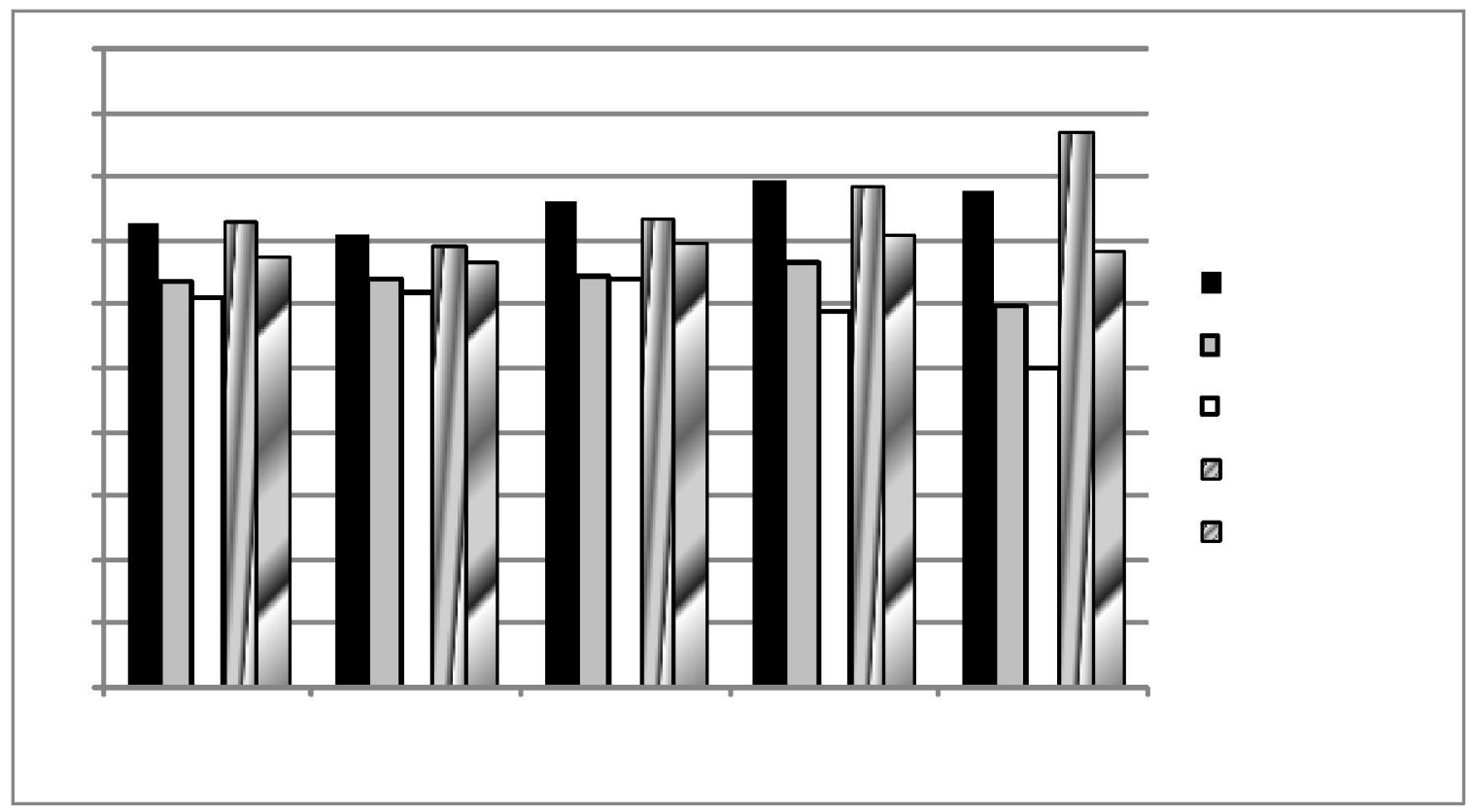

Figure 4. Education Group Comparison

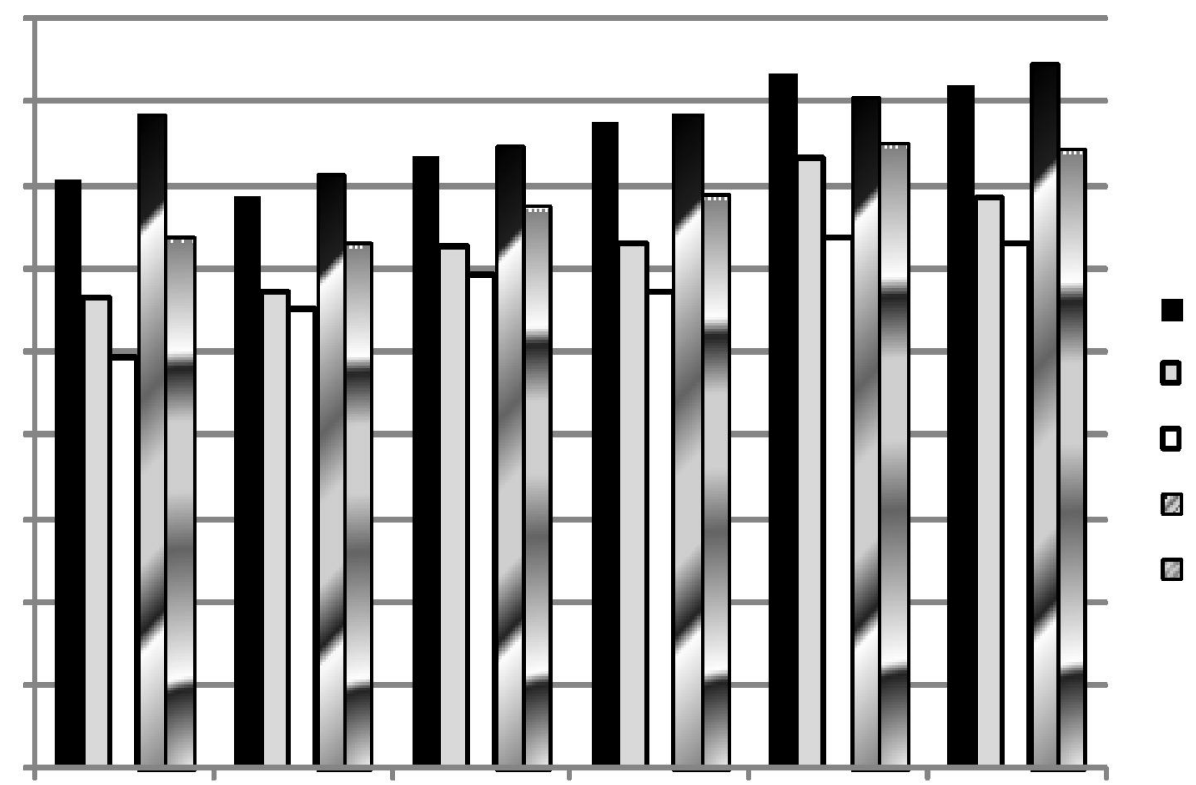


Figure 5. Internet Use Comparison

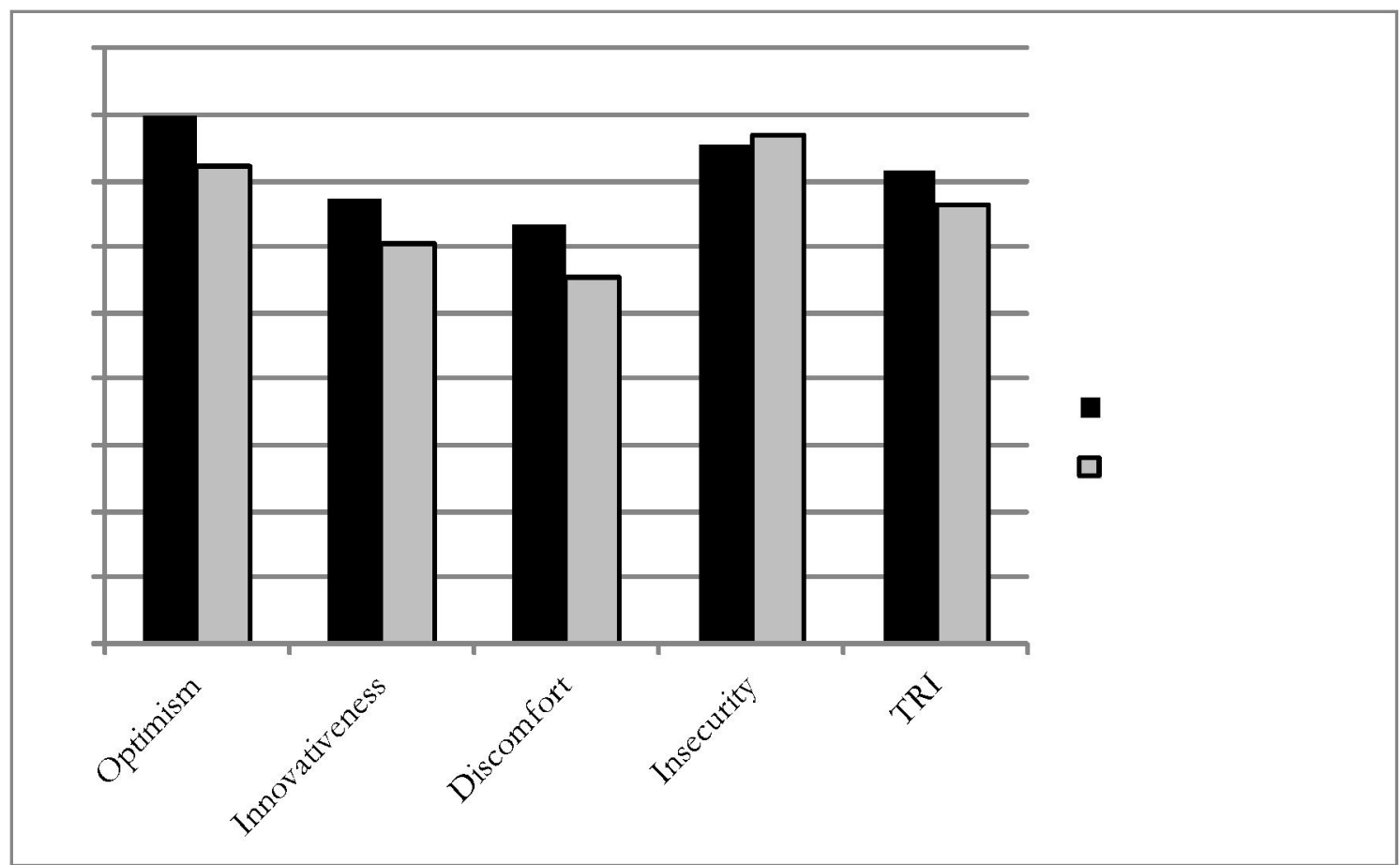

\section{Discussion}

By using the TRI developed by Parasuraman (2000), the purpose in this study was to examine technology readiness levels and to investigate the extent of internet adoption among entrepreneurs in SMEs in Bandung city. Demographic characteristics, business sector, and internet use as e-commerce to promote their products are also discussed due to their possible relationship to technology readiness. The results show the benefit of investigating the profile and background of the entrepreneur and his/her willingness to use/adopt technology to accomplish their goals in their home and working life. The overall TRI score (mean $=3.35, \mathrm{SD}$ $=0.84)$ indicates that the entrepreneurs are medium in terms of their technology readiness. There are significant differences in terms of technology readiness across various demographic variables (e.g. gender, education, income and ages).

From the result, it can be seen from the descriptive analysis that entrepreneurs score medium on Technology Readiness (optimism, innovativeness, discomfort, and insecurity). This result does not support a previous study (Jaafar et al. 2007) that examined technology readiness among managers in Malaysian construction firms. That study found that managers exhibited high levels of innovativeness and optimism and they also experienced considerable discomfort and insecurity. Compared to the study by Jaafar et al. (2007), which was conducted on construction firms, we found that entrepreneurs of SMEs in Bandung city scored lower on technology readiness.

With regards to the gender variable, only innovativeness was found to be significantly 
different compared to the other variables. This finding is in line with another previous study (Demirci and Ersoy 2008). Their study aimed to examine Technology readiness for innovative high-tech products, based on t-test results for the innovativeness factor it was found that male respondent values were assessed as higher than those of female respondents. The result supports previous research by Venkastesh et al. (2000) which found that the determinants of technology adoption and usage behavior confirmed that attitudes toward using technology was more salient to men.

According to the age variable, innovativeness and discomfort were found to be significantly different compared to the other variables. Morris et al. (2000) suggests that there are clear differences with age in the importance of various factors in technology adoption and usage. Although people feel that they can use the technology without help from others, always follow the development of technology, and have fewer problems than other people in making technology work. But few of them also feel uncomfortable and have the perception that the technology is not intended for ordinary people. Some high-tech products are only available with English for use or instruction, so they argue that these technologies are not offered in an understandable language. When seen from the descriptive result of education levels, we found that most of the elder entrepreneurs were only educated to senior high school level. So we suspect that their English language skills are very low, but it can be used as material for further research on the level of English language skills among entrepreneurs. So, the result support Jaafar et al. (2007) that discomfort was found to be significantly different.

The next result is that level of education plays an important contribution to the
TRI. This result supports Jaafar et al. (2007) who found that respondents with a high degree-level education also score higher on technology readiness compared to other groups. Entrepreneurs who have a high level of education have optimism and innovatiness but they also have high discomfort and insecurity levels. This can happen because the entrepreneurs who have the benefit of higher education have the ability to analyze, to judge something by looking at the positive and negative terms, so they are more cautious in adopting the technology. Actually, people who have high education have a high willingness to try new things and have optimism that technology can ease their workload.

With regards to income, we found that optimism, discomfort, and insecurity were found to be significantly different. This finding was not in line with a previous study (Demirci and Ersoy, 2008) that none of the factors of technological readiness were statistically different according to average income. We see that the entrepreneurs, who have higher incomes, have a high level of optimism. They have seen the benefits of the technology for their work. But here we see that the higher the income, they also have high levels of insecurity and discomfort. These high levels of insecurity come from the lack of security available online in Indonesia when using credit cards for transactions, or that private data may be viewed by anyone, and that they feel uncomfortable when there is a lack of person to person interaction when only dealing with a machine. This could be due to that sense of discomfort and insecurity which arise as a result of still not having a lot of knowledge about the ways of doing business online. We can conclude that their readiness for e-commerce services is still low. From the results of the adoption of the internet to promote products, only about 36.3 
percent use it. If viewed from the TRI, we found that the innovativeness was significantly different between entrepreneurs who adopt the internet and those who do not.

\section{Conclusion and Recommendation}

Measuring technology readiness and internet adoption among entrepreneurs provides new insight for SMEs and the Indonesian government to analyze readiness of technology and the extent of adoption of the internet in SMEs. Based on our findings, we then purpose the following recommendations for entrepreneurs in SMEs as well as for parties involved in supporting the enterprises including government, banking, telecommunication companies, and universities.

Firstly, the role of the Indonesian government is to promote the use of technology among SMEs. The Government must lead ecommerce users, various business and related activities by the private sector to move online. The Government should provide education on the importance of the use of technology, particularly the use of e-commerce for SMEs. Regarding the discomfort and insecurity problems that SMEs take note of in considering whether to involve in e-commerce, such as where and how the payment is made, when the transfer of goods takes place (before, during or after the transaction), whether the transaction is Business to Business or Business to Consumer, and whether the delivery of goods can be traced, the Government should act. To address these concerns, the Government can guarantee security in e-commerce transactions through the establishment of a Certification Authority, which can verify the identity of the seller and buyer, check transactions and security pro- cedures, and issues digital certificates. In addition, from the discussion above, we found that there are levels of technology readiness among adopters and non adopters. Therefore, the Government should campaign that education is important for entrepreneurs, as entrepreneurs who have higher levels of education are better prepared to compete with entrepreneurs from around the world, and ready to build global businesses. They are more willing to try new things and dare to face the challenges in this fast-paced world. Moreover, the Government should encourage big businesses and corporations to transfer technology to SMEs by offering them free training in ICT and e-commerce. Because technology must be easier to use, more affordable, and implemented from a local perspective, the Government can work together with IT companies to provide software that is easy to use and offered in local languages to breakdown the perceived complexity of IT.

Secondly, the banking industry plays an important part in supporting the development of SMEs. E-commerce products and services are also offered by banking organizations to carry out their transactions without necessarily coming into physical contact with their clients. These services include Automatic Teller Machines (ATMs), Electronic Fund Transfer (ETF), mobile banking, online banking, Electronic Data Interchange (EDI) and telecommunication services. According to the result, only 36.3 percent of entrepreneurs who using internet. Awareness and knowledge about banking products is still limited, entrepreneurs who used internet perceived that activities online cause discomfort and insecurity. They do not trust that online transactions will be safe, such as giving credit card information over the internet. Banking industry should help entrepreneurs to reduce anx- 
ious to use internet or technology adoption. The banks should introduce the use of e-commerce to their customers by educating them about it and the advantages that come with its use. Moreover, the banks can use sms messaging services to spread the news of the benefits of implementation of e-commerce, such as mobile banking, for those who cannot access internet services. To support the growth of entrepreneurs in Indonesia, the banks can provide incentives to individuals to become entrepreneurs by lowering loan rates. Also, to increase e-commerce, banks should give incentives to entrepreneurs who are willing to use e-commerce in their business operations and extending credit that facilitates them to use ICT and e-commerce.

Thirdly, telecommunication companies can be good partners with SMEs. Good network infrastructure and localization of content are needed to support SMEs. Without powerful and cheap telecommunications and other information services, SMEs will not able to operate online. Telecommunication companies should work together with the Government to develop electronic community centers, especially in rural areas to allow access to information, and the sharing of the same, to serve as a place for training to increase skills and knowledge about IT, communication, and also content development. This electronic community center can also provide market information for and between farmers in rural areas. Besides that, these centers facilitate trading with SMEs and with other companies in the international market. They can also serve to promote campaigns to propagate information to SMEs about ecommerce, success stories, benefits and handling problems related to the use of IT and e-commerce. Building awareness can be implemented through free training courses, workshops on e-commerce, and information centers to assist SMEs.

Universities are now playing a more significant role in the development of social and national economic growth (Co and Mitchell 2007; Mok 2005). With regard to entrepreneurial development, universities, as a seedbed of entrepreneurship, play a functional role in promoting entrepreneurship education to develop regional economies and societies (Binks et al. 2006; Bygrave 2004; Co and Mitchell 2006; Hartshorn 2002; Wilson et al. 2003). In Indonesia, entrepreneurship education has recently become focused in universities. These universities are also expected to play a full role in providing curriculum on entrepreneurship and build awareness of the importance of education for entrepreneurs. Universities must be able to develop individual entrepreneurship education and provide training programs. These programs are intended to increase entrepreneurial knowledge and skills, and provide training and counseling to improve business performance. Entrepreneurs who have business problems are also given advice and guidance to manage their business. In addition, university students should be involved in real entrepreneurial situations by working (through training programs) with entrepreneurs in their SMEs. University students are students studying business, information technology, economic and engineering etc. at the Undergraduate level, Master of Management or MBA program, and Doctoral program. Students can obtain experience and implement their knowledge to help entrepreneurs for solving their problems in doing business. The type of training that can be provided by universities to entrepreneurs includes knowledge of technology use, financial planning, leadership, international business trade, market research 
and English courses. We consider that these are important for the following reasons. Training on the use of technology will reduce insecurity in the use of technology, encouraging entrepreneurs to try and put into practice what they have been taught into the running of their business. Also, training about financial planning is necessary for SMEs to be able to manage their finances properly, so that they can use the income to be able to expand their business. Leadership training is considered important for entrepreneurs, to show how they can be good leaders who are able to manage their employees and responsibilities in the face of obstacles and challenges. Besides that, knowledge about international business and trade is necessary for them, including export and import rules and regulations, international business law, how to determine which countries offers favorable trading opportunities, how to enter foreign markets, and how to run a business overseas, so they can figure out a strategy to expand their business abroad. Then knowledge about the introduction of market research is necessary to enable them to analyze the opportunities that exist around them, measuring the level of customer satisfaction, measuring the effectiveness of advertising they have done so as to create better value for customers and generate larger profit. We noted concern about the language skills of entrepreneurs, some of them feel discomfort that there is no such thing as a manual for a high-tech product or service that's written in plain language. We presume that the English language skills of entrepreneurs are at a low level; this will be an obstacle to their intentions to use technology and to expand internationally. To overcome this language barrier, we encourage universities to help entrepreneurs to learn the English language. The importance of foreign language skills cannot be overlooked in the development of trading relationships and businesses with foreigners.

For SMEs in developing countries, ecommerce offer the benefits of cost reduction of information searches and transaction costs (ex. increase operating efficiency-reducing time for payment, loan processing etc.). This study makes a contribution to assessing how the variables of technology readiness are related to technology acceptance of e-commerce in SMEs. Effectively managing technology readiness as a major component of a company's business process will make an important contribution to the organization's business performance. Finally, it is necessarry to build an understanding of optimism and innovativeness as well as reducing discomfort and insecurity toward technology among entrepreneurs.

It is appropriate to mention the limitations of this study. First, the sample size is small so that cannot be used to describe the whole population of entrepreneurs in Indonesia. For future research, sampling should be done in many cities in Indonesia. This research was only conducted in 18 sectors, so that many sectors where SMEs operate have not been included in this study. We would argue that any further research must increase the sample size, to allow representation from each sector, so we can examine the technology readiness of all business sectors. In addition, another limitation in our study is that the study was done on a group with different educational backgrounds. The differences in income levels and educational backgrounds may influence entrepreneurs against new technologies. Further research on a more diversified sample could generate a more detailed insight into the technology readiness among entrepreneurs. This study also involved students and non students. Further research 
could separately study student entrepreneurs and non student entrepreneurs, so research can be focused to give recommendations between each segments. Any future research also needs to identify external factors, such as environment. When organizations face a complex and rapidly changing environment, innovation is both necessary and justified (Pfeffer and Leblebici 1977). Environmental factors such as demand from customers, pressure of competition, pressure from suppliers, etc. conceivably create a need for firms to adopt IT related innovation such as e-commerce. This limitation restricts the ability to investigate e-commerce adoption only in selling products; future research should examine market focus (local area, national area, regional area, and international) and levels of IT skill. Third, the research model should be developed to identify factors potentially affecting SMEs' adoption decisions.

\section{References}

Al-Qirim, N. A. Y. 2003. E-commerce in the aerial mapping industry: A New Zealand case study. Journal of Systems and Information Technology 7 (1/2): 67-92.

Berthon, P., M. T. Ewing, and J. Napoli. 2008. Brand management in small-to-medium sized enterprises. Journal of Small Business Management 46 (1): 27-4.

Binks, M., K. Starkey, and C. Mahon. 2006. Entrepreneurship education and the business school. Technology Analysis and Strategic Management 18 (1): 1-18.

Bouchard, L. 1993. Decision criteria in the adoption of EDI. Proceedings of the Thirteenth International Conference on Information Systems. Orlando, FL.

Cho, B., U. Kwon, J. W. Gentry, S. Jun, and F. Kropp. 1999. Cultural values reflected in theme and execution: A comparative study of U.S. and Korean television. Journal of Advertising 28 (4): 59-73.

Co, M. J., and B. Mitchell. 2007. Entrepreneurship education in South Africa: A nationwide survey. Education and Training 48 (5) (January): 348-359.

Demirci, A. D., and N. F. Ersoy. 2008. Technology readiness for innovative high-tech products: How consumers perceive and adopt new technologies. The Business Review 11 (1). Cambridge.

Fraser J., N. Fraser, and F. McDonald. The strategic challenge of electronic commerce. Supply Chain Management: An International Journal, 2000, 5(1): 7-14.

Jaafar, M., T. Ramayah, and A-R., Abdul Haziz. 2007. Technology readiness among managers of Malaysian construction firms. Engineering, Construction and Architectural Management (14) (2):180-191.

Grandon, E., and J. Pearson. 2004. Electronic commerce adoption: An empirical study of small and medium US businesses. Information and management 42): 197 - 216.

Hartshorn, C., and P. Hannon. 2002. Paradoxes in entrepreneurship education: Chalk and talk and cheese? Paper presented at the 25th ISBA National Small Firms Conference: Competing perspectives of Small Business and Entrepreneurship, Brighton, 1-19 November.

Houghton, K. A., and H. Winklhofer. 2004. The effect of website and e-commerce adoption on the relationship between SMEs and their export intermediaries. International Small Business Journal 22 (4): 369-388. 
Iacovou, L., I. Benbasat, and A. Dexter. 1995. Electronic data interchange and small organizations: Adoption and impact of technology. MIS Quarterly 8 (2): 465 - 485.

Karakaya, F., and T. Shea. 2008. Underlying motivations for establishing e-commerce business and their relationship to e-commerce success. Journal of Internet Commerce 7 (2): 153-179.

Knight, G. 2000. Entrepreneurship and marketing strategy: The SME under globalization. Journal of International Marketing 8 (2): 12-32.

Machacha, L. 2002. Impact of information technology on small and medium enterprises (SMEs) in Botswana. Proceedings (April 3-6: 277-82) of Expanding the Horizons of African Business and Development: The International Academy of African Business and Development International Conference, Port Elizabeth.

McMahon, R. G. P. 2001. Business growth and performance and the financial reporting practices of Australian manufacturing SMEs. Journal of Small Business Management 39 (2): 152-164.

Lin, C-H., H-Y. Shih, and P. J. Sher. 2007. Integrating technology readiness into technology acceptance: the TRAM model. Psychology and Marketing 24 (7): 641-657.

Mok, K. H., 2005. Fostering entrepreneurship: Changing role of government and higher education governance in Hong Kong. Research Policy 34: 537-54.

Molla, A., and P. S. Licker. 2005a. eCommerce adoption in developing countries: A model and instrument. Information and Management 42 (6): 877-99.

Meuter, M., M. Bitner, A. Ostrom, and S. Brown. 2005. Choosing among alternative service delivery modes: An investigation of customer trial of self-service technologies. Journal of Marketing 69: 6183.

Nunnally, J. C., 1978. Psychometric Theory (ed. ${ }^{\text {nd }}$ ). New York, NY: McGraw-Hill.

Parasuraman, A. 2000. Technology readiness index (TRI): A multiple-item scale to measure readiness to embrace new technologies. Journal of Services Research 2 (4): 307-20.

Pare, G., and L. Raymond. 1991. Measurement of information technology sophistication SMEs. Proc. Admin. Sci. Association of Canada: 90 - 101.

Pflughoeft, K. A., K. Ramamurthy, E. S. Soofi, M. Yasai-Ardekani, and F. Zahedi. 2003. Multiple conceptualizations of small business web use and benefit. Decision Sciences 34 (3): 467-513.

Poon, S., and P. Swatman. 1999. An exploratory study of small business internet commerce issues. Information and Management 12: 9 - 18.

Ramayah, T., M. Jantan, R. Mohd. Roslin, and R. Siron. 2003. Technology readiness of owners/managers of SMEs. The International Journal of Knowledge, Culture and Change Management 3: 475-86.

Roberts, B. W., and W. F. DelVecchio. 2000. The rank-order consistency of personality traits from childhood to old age: A quantitative review of longitudinal studies. Psychological Bulletin 126: 3-25.

Samad, N. A. 2007. Positioning Malaysian SMEs in the global. Proceedings of Persidangan Kebangsaan IKS 2007, Kota Kinabalu: Universiti Utara Malaysia.

Sarosa, S., and D. Zowghi. 2003. Strategy for adopting information technology for SMEs: Experience in adopting email within an Indonesian furniture company. Electronic Journal of Information Systems Evaluation $6(2): 165-176$. 
Saffu, K., J. H. Walker, and R. Hinson. 2008. Strategic value and electronic commerce adoption among small and medium-sized enterprises in a transitional economy. Journal of Business and Industrial Marketing 23 (6): 395-404.

Seyal, A., and A. Rahman. 2003. A preliminary investigation of e-commerce adoption in small and medium enterprises in Brunei. Journal of Global Information Technology Management 6: 6 - 26.

Radstaak, B., and H. Ketelaar. 1998. Worldwide Logistics: The Future of Supply Chain Services. The Hague: Holland International Distribution Council.

Ricciuti, M. 1995. Database vendors hawk wares on internet. Info Word (9-10 January): 17-27.

Rodgers, J., D. Yen, and D. Chou 2002. Developing e-business: A strategic approach. Information Management and Computer Security 10 (4): 184-192.

Tan, J., K. Tyler, and A. Manica. 2007. Business-to-business adoption of eCommerce in China. Information and Management (44) (3): 332-51.

Thong, J. Y. L. 1999. An integrated model of information systems adoption in small businesses. Journal of Management Information Systems 15 (4): 187-214.

Thong, L. 2001. Resource constraints and information systems implementation in Singaporean small businesses. OMEGA 29: 143 - 156.

Venkatesh, V., M. G. Morris, and P. L. Ackerman. 2000. A longitudinal field investigation of gender differences in individual technology adoption decision-making processes. Organizational Behavior and Human Decision Processes 83 (1): 33-60.

Ministry of Cooperatives and Small and Medium Enterprises Republic of Indonesia. 2012. Data UMKM. Available at: http://www.depkop.go.id/index.php?option=com_phocadownload\&view= sections\&Itemid $=93$ 
